Article

\title{
Black Deaths Matter Earning the Right to Live: Death and the African-American Funeral Home
}

\author{
Candi K. Cann $\mathbb{1}$ \\ Baylor Interdisciplinary Core, Baylor University, Waco, TX 76798, USA; candi_cann@baylor.edu
}

Received: 5 June 2020; Accepted: 23 July 2020; Published: 29 July 2020

\begin{abstract}
Black Deaths Matter: Earning the Right to Live-Death and the African-American Funeral Home recounts the history of black funeral homes in the United States and their role in demanding justice for bodies of color and the black community. Through funeral pageantry and vigilant support for local communities, the African American funeral home has been central to ensuring that not only do Black Lives Matter, but black deaths count and are visible to the larger community. This paper is a slightly expanded version of the plenary talk for the Centre for Death and Society's Politics of Death Conference at the University of Bath on 9 June 2018. This research and talk were supported by The Louisville Institute under the Project Grant for Researchers.
\end{abstract}

Keywords: death; African American funeral homes; African American deathways; George Floyd; Emmett Till; Black Lives Matter; funeral home

\begin{abstract}
"The trouble with us is we are always preparing to die. You ask a white man early Monday morning and ask him what he is preparing to do ... he is preparing to start a business. You ask a colored man ... he is preparing to die." Booker T. Washington ${ }^{1}$

"The death of black subjects or the invisibility of blackness serves to ward off a nation's collective dread of the inevitable. Someone else bears the burden of the national id; someone else-always already—dies first.". Sharon Patricia Holland ${ }^{2}$
\end{abstract}

\section{Introduction}

At 10:22 a.m. on Sunday, 15 September 1963, a bomb exploded in the basement of the Sixteenth Street Baptist Church in Birmingham, Alabama. Afterward, at the funeral, the caskets were kept closed, as the mourners grieved the continuing violence against people of color-even children, and "Claude Wesley's refusal to open his daughter's casket to the public reflected a deeper shift in the psyche of the national civil rights campaign. The price of the "non-violent" struggle was getting too high and the deaths (and closed caskets) of Wesley, McNair, Collins, and Robertson symbolized that cost as nothing else could have." 3 The bombing of African American churches was not new, nor were the deaths of innocent African Americans. What was new that day, though, was the mixture of innocence, childhood, and Christianity in such a way that white Americans could no longer turn a complacent eye towards the violence directed towards black bodies. When Emmett Till was brutally murdered and his body thrown in the Tallahatchie River, some tried to excuse the violence with salacious rumors of a youthful flirtation initiated by Till. In contrast, the bombing in Birmingham could not be excused or lied away. The girls were young, dressed for church, and serving as acolytes that day, and they

\footnotetext{
(Washington 1995, p. 59).

(Holland 2000, p. 38).

(Renata n.d.).
} 
were the only casualties in the Birmingham bombing. Their bodies sealed tightly in closed caskets for their burials symbolized a refusal to place black bodies on display. Closed caskets signalled that this funeral was both figuratively and literally a closed affair, meant for those who belonged in the circle of mourning family and community. Black bodies-lynched, mutilated, chopped up, on display and serving as testimony and witness to injustice and cruelty-but also, often the spectacle and specter of white violence inflicted on bodies of color-were now hidden in closed caskets, mourned by their families as little girls and not, like Emmett Till, as symbols. Open caskets and closed caskets were symbolic — and spoke-through display on the one hand, and inaccessibility on the other. ${ }^{4}$ Deaths served as witness to lives, but sometimes bodies could be sacred. The Black Lives Matter movement would again, sixty years later, insist on the agency of black lives through corpses, spotlighting death to recover the value of life.

The erasure of cemeteries of enslaved people through the burying of bodies without tombstones or burial markers so that their histories, contributions, and names would be forever lost, the segregation of cemeteries and the refusal to care for the upkeep of the burying grounds, the prohibitions, and laws that outlawed funerals where families and communities could mourn the deaths of their loved ones, the hiding away of black bodies in funeral homes that were only utilized by communities of color so that the epidemic of murders and the mutilation of bodies could continue to go unseen and unacknowledged and hidden away and denied—all of these show just how much black deaths matter. Enduring under incredible oppression, the story of the African American funeral home is also a story of resilience, of strength, and of power, fortunes, and identity formations, as the funeral home became a place of fortitude, character, and community.

\section{Deathcare Segregation and Burial Societies}

Nowhere is the continued and persistent segregation in the contemporary United States still as evident as in the deathcare industry. First separated along racial lines during American slavery, both the funeral home and the undertaker mirrored the segregation found in houses of worship and the community at large. ${ }^{5}$ Because enslaved people were initially prohibited from gathering in groups, ${ }^{6}$ it was difficult for African Americans to host and hold a funeral for their loved ones when they died, and many early graves of those who died were unmarked or simply left untended. ${ }^{7}$ Bodies of the enslaved were often buried without any kind of religious ritual or ceremony, but in some households, the enslaved were permitted to gather to bury and mourn their dead, just as they were occasionally allowed to worship congregationally. Tiffany Stanley writes that "From their earliest incarnations, black funerals were political, subversive-a talking back to the powers that be. Particularly in the 17th and 18th centuries, if slaves were allowed to bury their own dead and craft their own rituals, away from the overseeing eyes of whites, they could plan for their freedom, spiritually and physically." ${ }^{8}$ Funerals were symbolic of alternate worlds in which blacks could imagine a world with freedom-whether in this life or the next. Free blacks in the north formed burial societies through their churches, and the undertaker quickly became an esteemed and important member of the black community. Funeral historian Suzanne E. Smith argues that the funeral became a venue for African-Americans to honor the dead in a way that they had not been honored in life, while also providing an opportunity to gather

4 Anna Belle Kaufman writes that "The very fact of being boxed shows us that the contents are important to someone in some way: whatever is inside is being protected, collected, saved." (Kaufman 1996). Open and closed caskets hold significance to the grieving - they are intentionally used to reveal or to hide and conceal.

5 (Massey and Denton 1993) for more on racial segregation in churches.

6 The Negro Act in 1740, passed in the state of South Carolina and quickly enacted elsewhere, made it illegal for enslaved people to gather in groups, earn money, raise food, or learn to write, and also gave slave owners the right to kill those viewed as rebellious. This made it quite difficult for enslaved people to gather for funerals. For more, see (Olwell 1998).

7 (Arnold 2016). Arnold is creating the first database on enslaved Americans, and documenting all known burial sites of enslaved people. http://www.memorializeamericanslavery.com/, last accessed 8 April 2016.

8 (Stanley 2016). 
and discuss freedom from slavery. The limited opportunities to gather may also have helped lead to the practice of sitting with the body prior to its burial, and the importance of the participation of the corpse in the funeral itself, still found in contemporary black funerals. ${ }^{9}$ Extending the mourning time through extended care of the body allowed the black community to come together and strengthen social bonds and kinship ties, under the guise of mourning.

Azella Valentine reinforces this observation through her study of the contemporary African American funeral home industry and the contemporaneous emergence and popularity of the American black church and the formation of Christian burial societies. She writes, "Black churches began forming Burial Societies. They collected money from church members to pay for their funerals, coffins, and graves. (This is a forerunner to what we now know as pre-need funeral plans, where a person can pay, in advance, monthly towards funerals). Black funeral homes began opening their doors at this time because there was no money to support these businesses."10 The first African American Burial Society was founded in 1787 in Philadelphia, other societies soon followed suit, and in 1790, the Free African Society in Philadelphia purchased land in Potter's field so that the society could bury their dead. These burial societies ensured a good burial, the purchase of cemetery land enabled by collective donations, and sometimes, a small stipend for widows and children left behind. Burial societies were not exclusive to the black community but were popular among various other ethnic communities across the United States who sought to bury their dead with traditional customs.

When people came from Europe, they banded together with people from their towns, says Florence Marmor, 75, a woman who studies Jewish genealogy and had her own run-in with a burial society-in her case, over her own grave. She explains that burial societies sprouted up as one way to keep people together. "They didn't register with the government. They had to bury their dead, and they wanted to bury them among their own people." As time passed, burial societies literally took over some cemeteries-controlling up to 80 percent of the land, particularly in Jewish cemeteries. "In effect, the burial society land is a cemetery within a cemetery," says Joel Barkin, a spokesman for the office of the Secretary of State, which oversees cemeteries. ${ }^{11}$

It was no different in the African American community, where cemeteries were purchased for the burial of African Americans, ${ }^{12}$ and the rise of both the insurance business and the African American funeral home business were some of the few businesses that black Americans were allowed to own and run. Due to the refusal of whites to take care of black bodies, even in death, burial societies were often first to emerge in communities of Africans, both free and enslaved. In fact, the first known sickness and burial organization, the "Free African Society" was founded in Philadelphia in 1778 by Richard Allen, the founder of Mother Bethel African Methodist Episcopal church and Absolom Jones, an Episcopal preacher.

These insurance societies were no small business. Usually, they met weekly, and collected dues ranging based on one's salary. These dues were then distributed according to the need for sickness and/or death. DuBois, in 1899, wrote of the impact of burial societies in Philadelphia:

By 1838 there were 100 such small groups [sickness and burial organizations], with 7448 members, in the city. They paid in $\$ 18,851$, gave $\$ 14,171$ in benefits, and had $\$ 10,023$ on hand.

\footnotetext{
(Homegoings 2013).

(Valentine n.d.).

1 (Rayman 2009).

12 Burial societies continue to be of great importance in Africa today, and are sometimes seen as having competing interests with the Church, as many burial societies have their meetings on Sundays at the same time as local churches. However, burial societies function not only to provide the community with good burials, but also often serve to actually nourish and feed the living through their elaborate funeral feasts. Thus, the meetings, during which refreshments and food are served, also function to provide sustenance to the community, and unfortunately, many churches find that their spiritual sustenance is no competition for the physical sustenance provided by the burial societies. For more on this, see (Semenya 2013).
} 
Ten years later about 8000 members belonged to 106 such societies. Seventy-six of these had a total membership of 5187. They contributed usually 25 cents to $371 / 2$ cents a month; the sick received $\$ 1.50$ to $\$ 3.00$ a week and death benefits of $\$ 10.00$ to $\$ 20.00$ were allowed. The income of these 76 societies was $\$ 16,814.23 ; 681$ families were assisted. ${ }^{13}$

This was no small amount. By today's standards, $\$ 16,814$ would be equal to somewhere between $\$ 539,000$ and $\$ 135$ million dollars, ${ }^{14}$ and the collected totals allowed for large amounts of capital to be pooled to help the community in Philadelphia while providing needed resources for the sick, dying and dead. These early burial societies were able to generate large amounts of capital, making the early rise of the burial insurance society-and later the funeral home-one of the more important and profitable businesses. Like the emergence of the African American hotel, black bodies generated income for the black community, since they were the ones responsible for their own well-being. ${ }^{15}$

\section{A Brief Case Study of Early Burial Societies: Mother Bethel African Methodist Episcopal Church}

Mother Bethel African Methodist Episcopal Church in Philadelphia is the first African Methodist Episcopal Church established in the colonial United States and contains a rich repository of historical archives that document the importance of the early burial societies. The records of the United Daughters of Tapisco 1837-1840, for example, reveal a female church society that met weekly, collected dues, provided relief for the sick, and helped organize funerals for the dead. Women had a valuable and visible role both in the community, one that later continued in the funeral home, providing the funeral business with both finances and labor. A survey of this society and others revealed an initial preoccupation with burial and purchase of land for internment, but records reveal that as years went by, sickness and life circumstances and needs seemed to figure a larger role. Various fines were imposed on society members for being late to church, coming late to the meetings, not attending church, talking too loudly, etc., and in this way, burial societies also functioned as keepers of morality in addition to precursors of insurance for burial. Societies were thus not only early precursors to the later boom of successful insurance companies, but also functioned as informal networks and enforcers of community identity and values.

One of the very first tasks of the societies at Mother Bethel was to raise the funds to purchase a burying ground for Africans, both free and enslaved, living in colonial Philadelphia. Due to restrictions on burying bodies of color within the city limits of Philadelphia, the initial burying ground was located outside of Philadelphia proper, in the land directly across from the church and extending half a mile beyond in an area known as Southwark, and more than five thousand graves are believed to have found their final resting place in the burying ground between the years of 1810 and 1864 . When Richard Allen purchased the burying ground in 1810, the church societies were finally able to utilize society funds for other things besides burial and funeral ceremonies, and the direction of these early church societies shifted from concern for the dead to concern for the living. Society records reflect this shift, with financial records reflecting donations and society dues going to help those who were sick in the community or in need of temporary aid, rather than funding the burying ground.

Church Society records gradually shifted over time from burial societies to relief societies, reflecting a movement from a preoccupation of burial to a desire to better help the living. Following the Civil War, the burial societies were replaced by the insurance industry (the societies themselves stayed in existence though their purpose had shifted), which would help provide for burials of African Americans

13 (DuBois 1899, p. 222).

14 See MeasuringWorth.com, (Measuring Worth Website n.d.) for various estimates of currency values between 1848 and 2018. https://www.measuringworth.com/calculators/uscompare/relativevalue.php, last accessed 31 July 2018. The smaller number is the real price value, which only takes into account annual inflation rates, while the larger number reflects the percentage value of the entire economy; in other words, the income generated through burying societies was not insignificant and represented a fair proportion of the economy in the United States at that time.

15 African American hotels were another successful black-owned business, since people of color were not allowed to stay in white-owned and patronized businesses. For more on this, see (Armstead 2005). 
who could not trust white insurance societies known for lynching or murdering its black clients. ${ }^{16}$ The insurance industry, along with the funeral industry, then became another substantial source of revenue within the early African American community. No longer associated with specific churches, the insurance industry would provide burials for those in the community who died, while churches busied themselves with the problems of life.

\section{Insurance: The Business of Insurance and the African American Market}

Burial societies can be seen as the precursor to the thriving insurance business that eventually emerged, and insurance societies were not merely financial, but social as well. When a member of the insurance society died, all members were required to attend the funeral, ensuring that the deceased's social network was represented, revealing both their status and kinship associations. Each burial society had special uniforms and badges which they wore to the funeral to distinguish them from other attendees. Funeral attendance was strict: the only excused absences were when a member was seriously ill. Thus, the insurance was not merely financial but communal and served to reinforce networks of affinity. However, the insurance business thrived out of necessity; from an economic standpoint, many had few other options. John Sibley Butler states, "The idea of economic detour is that Afro-Americans, especially in the period following the Civil War, were restricted by law from operating their business enterprises in an open market."17 Butler [goes on to] argue that the US Department of Commerce in 1939 recognized "a separate Afro-American market," and that blacks were expected to operate their business "only within their own group," while this expectation was never true for other groups such as the Japanese or Chinese [living in the United States]. ${ }^{18}$ That insurance societies were one of the more successful businesses to emerge out of economic detour, and the funeral home after that is no mystery-when they had little other business opportunities available to them. By the end of the 1930s, it was clear that the insurance business was a deeply profitable one, with over a billion dollars invested, and a minimum of $\$ 340,000$ in liquid funds. Since funeral home directors had first access to these funds, they quickly became the wealthiest people in the community, and often emerged as casual lenders, providing a sort of neighborhood banking system that supported the community. African American church burial societies-and later black-owned insurance companies-were thus essential to the foundation, and later success of, the contemporary funeral home which would become the nexus of the black community—both living and dead.

\section{Civil War and Early American Deathcare}

Another important influence in the formation of the black funeral home came from the American Civil War. Though technically fighting the war as freed men, black Union soldiers in the Civil War were assigned the less desirable duties of removing the dead from the battlefields, recording losses, embalming the bodies, and shipping them back to their families, providing the perfect training ground for contemporary preservation and embalming practices. ${ }^{19}$ Similarly, the newly freed African-American community in Charleston, South Carolina (many of whom were formerly enslaved) honored the fallen dead by erecting a graveyard for union soldiers. Twenty-eight African-American men, all from local Charleston churches, erected a wall surrounding the racecourse in order to properly bury the bodies of 257 dead Union soldiers, culminating in a ceremony that many today recognize as the first celebration

16 There are several noted instances in which white insurance salesmen would sell policies to African Americans and then turn around and lynch them in order to profit from the policies. For more on black-owned insurance companies and white racist policies, see (Chapin 2012).

17 (Butler 2012, p. 71).

18 (Ibid., pp. 72-73).

19 Though there is not much written on the African American funeral industry and its rich history, Arzella Valentine writes some lovely web-published pieces on the African American funeral industry. See (Valentine n.d.; Cann 2014) for more on the history of embalming and the role of both refrigeration and train transport in the transformation of the death care industry in the United States from the Civil War period to the present day. 
of Memorial Day. Newspaper accounts from that day write that there were as many as ten thousand people who brought flowers and attended the many sermons and prayers recited that day over the graves of the Union soldiers. Ministers from the various African American churches in Charleston gathered to honor those they believed had fought for their freedom in the Civil War. Historian David W. Blight writes,

The official dedication ceremony was conducted by the ministers of all the black churches in Charleston. With prayer, the reading of biblical passages, and the singing of spirituals, black Charlestonians gave birth to an American tradition. In so doing, they declared the meaning of the war in the most public way possible - by their labor, their words, their songs, and their solemn parade of roses, lilacs, and marching feet on the old planters' race course ... ${ }^{20}$

Thus, in what many believe to be the predecessor of the contemporary Memorial Day in the United States, the African American church and deathcare industry demonstrated their continued close affiliation even after the popularity of burial societies had diminished and been replaced by insurance companies.

The memorializing of the dead also revealed a need to continue the deathcare practices developed in the Civil War and the African American funeral home industry, like the insurance business along with it, grew and blossomed. As Kami Fletcher writes,

Utilizing the carpentry skills learned from and exploited by Whites through slavery, now Black men were using this knowledge to make coffins and properly prepare the deceased of their community for the afterlife at an economic gain for themselves ... Understanding that death, but more so the ceremonial prepping and sending off to the afterlife, was of high priority, undertakers were able to capitalize and fulfill a greatly needed service in the Black community. Once slavery was abolished and Blacks experienced the spatial freedom that comes from the absence of slavery, they immediately sought to take part in elaborate death ceremonies for their kin ... Now during this Reconstruction era with economic prosperity on the horizon, African Americans (who were adopting some Western cultural funerary norms) used expenditures as a way to signify their immense love for their deceased kin. Everything was extravagant and top-notch, mainly the casket and the hearse. At the turn of the twentieth century, hearses and high-class funeral carriages were where patrons were spending their money and where African American undertakers were receiving dividends hand over fist. ${ }^{21}$

Because of segregation and economic detour, the funeral home emerged as not only one of the more successful black businesses, but also a creator and cementer of identity.

\section{The African American Funeral Home}

As funeral homes popped up across the United States, they became safe spaces for people of color. Since funerals were one of the legal times in which the enslaved were allowed and encouraged to gather, and since white funeral homes did not want to treat bodies of color, funeral homes later became safe spaces for blacks to gather and commune. Funerals were not the only events held in funeral homes. Since funeral homes were often centrally located and had large open halls as part of their architectural layout, they also held community events such as dances, fundraisers, and community meetings. Since funeral homes held such an important space within their communities, they quickly began to function as makers of identity. ${ }^{22}$ Funerals allowed African Americans to reclaim their narrative in a space wholly undefined and not controlled by whites. This allowed for funeral homes to express their identity in ways that could not be expressed in other areas of shared social space.

\footnotetext{
(Blight 2002, p. 186).

(Fletcher 2013, pp. 174-75).

For more on reading on this, see my bibliography with Oxford on African American deathways: (Cann 2020).
} 
Funeral homes were also recoverers of dignity—funeral homes allowed families to recover their dignity in shared social spaces in which blacks were usually silenced, erased, not heard or valued. As the African American church, the funeral home offered a place where black identity mattered. One of the more obvious, yet often underappreciated aspects of the funeral home was its role as a tradition maker. Many ceremonies utilized songs passed down in the community and employed traditions that bonded the community (particular outfits for burial society, scripted gender roles for community members, etc.). The National Funeral Directors and Morticians Association (NFDMA), ${ }^{23}$ was initially established because the National Funeral Directors' Association (NFDA)—a largely white funeral home association - did not welcome black funeral home members. Eventually, the NFDMA became the cornerstone of the black community, publishing a magazine that became central to black American identity, and regularly sponsoring community events, educational scholarships, and discussed black identity. The NFDMA magazine even had monthly articles about pan-African identity, and followed the travels of a group of funeral home directors in their travels in Africa, encouraging dialogue between Africans and African Americans as a way to hold on to and cement their identity.

As the funeral home industry grew in importance, its sources of capital also grew both in size and importance. Similar to the earlier discussion on the growing importance of the insurance industry in the United States, black funeral homes held vast amounts of liquid capital resources and were often the first place black travelers went to when they needed help, money for their sick family, or even bail bonds. Funeral homes also frequently operated as banking resources for local communities who often had few places in which to invest their money. In addition to providing capital for the community, they functioned as centers of resources. Funeral homes, because they offered both safe gathering spaces and access to liquid assets, were one of the primary providers of resources for the community-whether it was a phone to call family and friends, a place to stay (and money to stay there), information on the local community (such as safe restaurants or hotels) for travelers, or money, the funeral home could be counted on to be a community resource. Funeral homes were expected to help the community, and in return, the community would purchase their burial services at the funeral home, often utilizing the same home for generations within a family. Along these same lines, funeral homes also operated as network hubs, connecting people across the country, and across the community. According to Butler, funeral home directors prided themselves on what they called service leadership, a style of leadership in the community that centered on serving that community and becoming indispensable within it. Service leadership, with its Christian undertones, was a successful business model within the African American funeral home and promoted what DuBois called self-help. In line with this, the funeral home industry (and the FDMA itself) regularly offered scholarships to its brightest members in the community with the hope being that those who received scholarships would become educated and return with a profession that could aid the community.

Finally, the funeral home was a hub of transportation, transporting both the living and the dead. From local dances, transportation around town to taking the ill to hospitals. In my interviews with Mr. Chestnut, the owner of Chestnut Funeral Home-one of Gainesville's oldest businesses, and believed to be the first African American funeral home in Florida, ${ }^{24}$ he recounted his days as both funeral director and paramedic, trying to help not only the bereaved families through his care of the dead but also providing services for the living. He was trained in the administration of oxygen and told me stories about trying to gauge whether he was visiting a home to pick up a living sick person or a dying (and soon to be dead) person. He said that it was the insurance laws implemented in 1965

23 One important difference between the two organizations apart from race, is that the NFDMA included morticians in their membership, while the NFDA only included funeral home directors. Thus, there is an implied class distinction between the two organizations, in that the NFDMA recognizes the trade of embalming, where the NFDA only recognizes ownership and funeral directing.

24 (Chestnut Funeral Home Website n.d.). The Chestnut Funeral Home was established in 1914 as Hughes \& Chestnut Funeral Home. Charles Chestnut Sr. has been called the grandfather of black funeral service in Alachua County—his grandson (Charles III) and great-grandson (Charles IV) continue to run the business today. 
that prevented him from continuing to help the sick since insurance companies refused to continue to insure combination ambulance/hearses. So, his role changed dramatically at that point since he was charged only with caring for the dead, and no longer responsible for caring for those who were sick. Another funeral home I researched, the J.F. Bell Funeral Home in Charlottesville, Virginia, ${ }^{25}$ was the precursor to the first integrated taxi company since its director initially offered rides to the community in its limos and hearses. Eventually, one of the founders of the funeral home decided to found a taxi company, which led to the foundation of Charlottesville's first taxi company that served both the populations of people of color and whites. In short, the funeral home was not merely a business opportunity but served as a nexus of community coalition and resource building that became central to black identity in the United States. The importance and role of the African American funeral home would continue to demonstrate its centrality in the American Civil Rights Era.

\section{Funeral Homes in the Civil Rights Era}

In the Civil Rights era, ${ }^{26}$ funeral homes continued to provide a safe haven for both individuals and their communities, expanding on their earlier role as resource providers. Funeral homes supplied transportation for civil rights leaders, in part because they had the resources, but also to protect them and keep them safe (few people thought to search or stop hearses since it was generally assumed they were only transporting the dead). Funeral homes also provided transportation to and from poll booths so people could vote. In this vein, funeral homes provided tents, chairs, and tables for voter registration in predominantly black neighborhoods to aide in the registration of voters. Often funeral homes would also provide bail bonds for protestors who had been jailed in protests. They also continued to furnish Combination ambulances, cars that functioned both as ambulance and hearse, with funeral directors trained in rudimentary first aid and transporting oxygen to people who had no way to either get to hospitals or receive emergency treatment. Since many hospitals continued to have quotas on treating bodies of color due to the continued existence of Jim Crow Laws, these combinations were often the first (and sometimes the only) step in emergency healthcare.

Funeral homes provided their tables, folding chairs, and tents to assist in voter registration and to mobilize activists for the community. In my interviews with the great-nephew (now a University of Virginia professor and doctor of medicine) of J.F. Bell Funeral Home's founder, he told me how his great-uncle had been central to the integration of voting rights in Charlottesville, explaining how J.F. Bell used to bring the funeral home's tables and chairs to the polling booths so that people could register to vote. Later, his great-uncle would serve on the local school board and help integrate the school system in Charlottesville. Funeral homes provided their spacious halls for meetings and auxiliary clubs in the community and were regular sponsors of educational scholarships for college, offering large financial grants to encourage education. Essentially, black funeral homes in the Civil Rights era provided sanctuary (money, food, transportation, and shelter) in times of crisis, in addition to the traditional services for the dead and providing comfort to the community. Poole Funeral Chapels, ${ }^{27}$ the funeral home responsible for conducting the funerals for two of the girls murdered in the Sixteenth Street Baptist Church bombings, also provided funds and other resources for activities that benefitted the community, sponsoring youth baseball teams, giving people rides to and from doctors'

25 (J.F. Bell Funeral Home Website n.d.). John Ferris Bell was born in 1890 and educated in Petersburg, Virginia, and upon graduation, taught tailoring for four years. He then trained as a Funeral Director and Mortician in Chicago, Illinois. Dr. John A. Jackson, his cousin from Petersburg who had become a dentist in Charlottesville, pointed out the city's need for a mortician. Mr. Bell moved from Chicago to organize the J.F. Bell Funeral Home which continues today as the oldest family-run funeral home in central Virginia and the area's oldest existing business owned by people of color.

26 The American Civil Rights era is generally thought to be the time period between the 1950s and 1960s, and was highlighted by the struggle for social justice for people of color. Though key legislation passed in this era advocated for the desegregation of schools and society, systemic racism continues to remain an issue, largely evidenced through unfair and predatory lending practices, and the continued practice of arresting and incarcerating people of color at much higher rates than whites.

27 (Poole Funeral Chapels Website n.d.). 
offices, buying shoes and school books for underprivileged children, and sponsoring gospel programs. In addition, funeral home facilities were used for community meetings, gospel singing group's practices, community programs, and church services for several local congregations. Young people in the neighborhood were allowed to practice music lessons on the Poole Funeral Chapel's piano and organ. African American funeral homes offered important social spaces, helped consolidate identity, served both the living and the dead, and helped forge a path for black lives through black deaths. These funeral homes served the living through their care of the dead.

Funerals, themselves, were also an opportunity to affirm black identity in a society that sought to erase it. They brought the community together and provided a safe space for outrage regarding oppression. Funerals in the Civil Rights Era were politically charged and sometimes served as platforms for speaking against oppression and white supremacy. Some core issues emerged in these funerals such as integration in cemeteries, the corpse as protest, the corpse as sacred and private, the funeral as spectacle, and the funeral as a protest march, and funeral directors were at the center of both setting the stage and organizing the ceremonies in a very public eye and in an extremely dangerous time. Due to the economic success and the abundance of resources, both in-network and financial capital, many of the leaders that emerged during and after the Civil Rights period had ties to the funeral home: Robert C. Henry, the first black mayor of Springfield, Ohio was a funeral home director, the first black mayor of Fayette, Mississippi-Charles Evers, elected in 1969-was a funeral home director. In 1970 of the first three African Americans elected to the South Carolina general assembly since reconstruction, two of them were funeral directors, the first and only black mayor of Raleigh, NC elected in 1972 was a funeral director, in 1974, the Ford brothers, whose father owned a funeral home, were elected to the US Congress, the Tennessee state senate, and the Memphis City council. Many prominent leaders found their origins in the funeral home and the business of death. ${ }^{28}$

\section{The National Funeral Directors and Morticians Association}

The National Funeral Directors and Morticians Association, Inc. (NFDMA) began its days as the Independent National Funeral Directors Association in 1924 before undergoing several name changes, and merging with both undertakers and embalmers, ${ }^{29}$ finally adopting its current name in $1957 .{ }^{30}$ The NFDMA represents approximately two thousand African American funeral homes ${ }^{31}$ and sees itself as not merely the representative of the black deathcare business, but also the protector of its interests, particularly since it emerged in its current incarnation in the middle of the American Civil Rights era. Though officially and legally integrated, segregation in the funeral home industry continues today, even in the ongoing commercialization of the funeral industry and the buyout of small mom-and-pop funeral home operations. Traditionally black funeral homes still continue to serve the black population even when the funeral home has been bought out by one of the large multi-national funeral industry conglomerates, ${ }^{32}$ partly explaining why corporate death industry workers are looking to train their personnel in cultural competence. Reginald McKinney, the owner of the McKinney Family Funeral Home in Jacksonville, Florida, states that when he first began working, he saw the effects of racial segregation first-hand. "In the funeral home that I interned in, the case-load was 100 percent black," he reflected. Now, McKinney has 15 years of experience as a funeral director, but he can still count the

28 Beyond the scope of this article but in need of further study is the economic relationship between the African American funeral home and the emergence of black leaders whose origins stem from either or both the insurance industry or the funeral home business. Just this brief listing of leaders whose families had ties to these businesses reveals the essential importance of the African American funeral home to American culture.

29 As mentioned earlier, the NFDMA includes the role of morticians/embalmers in its title heading, thus acknowledging the role and equal importance of those preparing the body, and not simply managing the funeral home itself.

30 (National Funeral Directors \& Morticians Association, Inc. Website n.d.).

31 There are varying estimates of the actual number of black funeral homes-though most estimate a total number of four thousand funeral homes that cater specifically to African American communities, the NFDMA represents about 2000 of these.

32 However, the corporatization of the deathcare industry may lead to shifting demographics in the funeral home industry (though on a very slow scale), so these changes should be tracked for future study. 
number of white families he has served in the last year on two hands. "Out of that 75 I serviced last year, I would say eight were actually white families," he said. ${ }^{33}$ The leadership of the deathcare industry is still largely segregated at the national level as well. The National Funeral Directors Association did not integrate its membership until the early 1960s, and remains mostly white in its membership, while the National Funeral Directors and Morticians Association, Inc., now integrated, remains mostly black.

The survival and future of the black funeral home are threatened by various factors-from corporate buy-outs of smaller mom-and-pop funeral homes to churches trying to stake out a claim for their constituents through commercial alliances, making deathcare precariously fraught. Regarding a deal made in the late 1990s between the National Baptist Convention (NBC) and the Loewen group, in which members of NBC churches would receive a ten percent discount on graves, vaults, tombstones, and other death accouterments, the NFDMA claimed that the National Baptist Convention did not value the personal care or the close historical association with black identity associated with NFDMA funeral homes that large corporations such as Loewen could not and would not provide. Andrew W. Nix Jr., owner of the Andrew Nix Funeral Home in Philadelphia and the treasurer of NFDMA at the time, argued, "Rev. Lyons and those black preachers are doing nothing but taking their 30 pieces of silver like Judas did with Christ." ${ }^{\prime \prime 4}$ The religious rhetoric employed by Nix reveals the close association of both the church and the funeral home to reinforcing African American identity within American society, and the level of betrayal felt by Nix over the American Baptist Convention's alignment with a corporate entity without a vested interest in African American identity.

It is in part because of the high homicide rates among young African Americans that the black funeral home industry is still considered to be one of the more profitable industries left in the African American community, and may in part be responsible for the large corporate buyouts of smaller black funeral homes. Homicides require added security, with guards and monitoring equipment, both of which can be built into the costs of funeral services and goods. Additionally, bereaved families of those who die young often purchase expensive funeral packages, investing the money they might have put towards their loved one's life, upgrading funeral goods and services (such as expensive caskets, and casket add-ons). Finally, African Americans tend to opt for funerals in which the body plays a significant role, diverging from the trend among white communities towards cremation or "green" burials. Funeral homes typically consider embalmment the cornerstone of the funeral package, as embalming the deceased generally means that visitation will be held in addition to the funeral service, and other funeral goods and services can be added on when the body is embalmed. A visitation requires not only embalming, but also funeral home rental, purchase of a casket (or at the very minimum a rental casket for the viewing), transportation from the funeral home/church to the graveyard, and refrigeration of the body. With the service of embalming usually costing two to three thousand dollars, funerals that opt to embalm are considered the most profitable. ${ }^{35}$ The Wall Street Journal reports that,

Federal statistics showing high mortality rates among young blacks and industry surveys showing that most blacks reject low-cost cremations in favor of high-markup burials have made them an attractive target to the industry's big players. But for the nation's estimated 4000, mostly family-owned black funeral homes, and the communities they serve, more than dollars are at stake. African-American funeral homes grew out of the ugliness of segregation to become mainstays of black community and culture. In many places, they remain among the last black-owned institutions catering to and supported almost exclusively by African-American consumers. Some funeral-home directors worry that, should they be forced aside by chains-or bought out by white-owned companies-the blow to the

33 (Long 2014).

34 (Henderson 1997).

35 For more on this, see (Cann 2018). 
African-American community will be enormous. "It actually frightens me," says O’Neil D. Swanson Sr., owner of two funeral homes in Detroit and another in Pontiac, Mich. "Before integration, every major city had a black hotel that we could be proud of. And all of those businesses were just killed off by chains. That just might happen to us."36

The funeral home industry has created one of the more profitable and successful industries for African Americans in the United States, an industry that has been key in establishing, maintaining, and reinforcing black identity in a society that continues to ignore the inequities of its healthcare system, and disregards the murder of its young African American men. Ironically, many feel that integrating the funeral home industry may actually undermine black identity in a time when black deaths have been largely ignored. Adonnica Toler, a historian of Ritz Theater and Museum in Jacksonville, Florida, says, "They [members of the white community] didn't want to live with you when you were alive, and they didn't want to spend eternity with you." 37 The black funeral home, then, offered a respite from a society that simultaneously wanted to separate itself, yet profit from, black lives and bodies.

Not only are black deaths invisible, but the African American deathcare industry, itself, seems to be largely ignored and understudied even in academia where it is, at best, an afterthought or a contrasting point. ${ }^{38}$ As Adkins asserts, the black funeral home continues to be presented and studied through the guise of tokenism, rather than an important part of the history-or counter-history-of the United States. This, in turn, allows the white funeral home to remain the primary documented (and studied) form of deathcare. ${ }^{39}$ This depiction of deathcare in the U.S., as discussed in the majority of both academic and popular literature reveals a highly monolithic and static understanding of dying, death, grief and deathcare, when the makeup of the American population is in flux and highly diverse. Dr. Ronald K. Barett, the recently deceased former head of the psychology department at Loyola Marymount University and a specialist in death and dying among the African American community, wrote in the mid-nineties that "The more I became involved with the literature of death and dying, the more disturbed I became at what seemed a conspicuous absence of published research on the African-American experience." 40 Not much has changed in the twenty years since he wrote these observations: death-particularly in non-white communities—remains highly segmented and a largely undocumented experience, with most of the literature on non-white death and dying relegated to ethnic studies, or included as a token differential to the mainstream white experience. What would they say, then about the current Black Lives Matter Movement?

\section{Black Lives Matter and The Contemporary Funeral Home}

The founders of the Black Lives Matter (BLM) movement ${ }^{41}$ describe it as "an ideological and political intervention in a world where Black lives are systematically and intentionally targeted for demise ... a call to action and a response to the virulent anti-Black racism that permeates our society." 42 The BLM movement, much like the civil rights movement of the 1950s and 1960s and the death of Emmett Till, was sparked by the death of Trayvon Martin. Many have called Martin the Emmett Till of our time, drawing parallels between the two because of the closeness in age and the circumstances that led to their violent deaths. Martin's death, like Till's, led the nation to reexamine the issues of race and

\footnotetext{
(Henderson 1997).

(Long 2014).

8 The segregation of the funeral home industry is rarely addressed in the academy and most books and articles discussing deathcare are actually studies of the death industry in white American culture, with occasional mentions of other diasporas as the outliers. Gary Laderman's 2005 popular and seminal book, Rest in peace: A cultural history of death and the funeral home in twentieth-century America, (Laderman 2005) for example, discusses the elevated status and the positive reception of the black undertaker in the African American community in comparison to that of the white undertaker, arguing that in comparison, the white undertaker is often viewed with some suspicion or possibly even disgust.

39 (Adkins 2003, pp. 10-13).

40 (Barrett 1995, pp. 80-92).

41 (Garza 2014).

42 (Jackson 2016).
} 
race relations while igniting youth-led movements. Beyond both of these cases is the fact that they entrusted the black funeral director with the handling of the remains. "Trayvon Martin's body was entrusted to Roy Mizell of Roy Mizell and Kurtz Funeral Home in Fort Lauderdale, Florida. ${ }^{43}$ During the course of the investigation, Martin's body was autopsied, and the medical examiner's official report showed a fatal gunshot wound and broken skin on his knuckles suggesting a fight. In contrast to that report, though, Roy Mizell, himself an activist and active member of the NAACP, gave an interview stating that "as far as his hands and knuckles, I didn't see any evidence that he had been fighting anybody." 44 Another funeral director at the Roy Mizell and Kurtz Funeral Home, Richard Kurtz, argued that "The story just does not make sense that Trayvon Martin was in this type of scuffle or fight," "In dressing the body we could see no physical signs like there had been a scuffle," he said. "I didn't see any knuckles' bruises and what have you, and that is something we would cover up if it would have been there. I did not see any signs of any cuts on his neck or face." 45 Funeral directors (and the funerals they orchestrate) become witnesses of injustice performed on bodies of color in the same way they offered witness to black bodies in the Civil Rights Movement.

The death of Freddie Gray at the hands of the Baltimore City Police was equally problematic. With his services entrusted to the funeral directors of Vaughn C. Greene Funeral Services in Baltimore ${ }^{46}$, the funeral was orchestrated in such a way that dignity and respect would be given to Gray and his loved ones while displaying evidence of injustice available for the public to see. Gray's funeral, as well as those of Mike Brown and Eric Garner, served as platforms that fueled the Black Lives Matter Movement. Similarly, George Floyd's funeral in June of 2020 served as a catalyst for widespread protest against police brutality towards bodies of color, with the Black Lives Matter movement finally gaining the traction it has long deserved. Floyd's funeral and memorial services took place in three locations over the course of six days-all handled by prominent African American funeral home, Fort Bend Memorial Planning Center. ${ }^{47}$ The first funeral was in the location of Floyd's death-Minneapolis, Minnesota, and the second one was held on June 6, in Raeford, North Carolina, where much of Floyd's family lives. The last funeral was held on June 8, in Houston, Texas, where Floyd lived for much of his life before moving to Minnesota a few years before his death, and where Fort Bend Memorial Planning Center is located. Fort Bend's funeral homeowner remarked that the one request made regarding Floyd's funeral was that it be grand:

"We were contacted by the family a day after Mr. Floyd passed away to conduct the services and facilitate the services for his celebration of life," Fort Bend Memorial Planning Center owner Bobby Swearington said. Swearington said Floyd's family asked that the funeral service be grand. "Not an easy thing to do with the magnitude and the amount of visitors that we are expecting to embark upon Houston when his services commence," Swearington said. "It's just so much that we are having to put together, we want to make sure that we are able to exercise social distancing, so we had to find a facility ... We've had just an outpouring of support from so many people," Swearington said. "People wanted to send carriages and doves and arrangements to the family. Artists, monument makers, just everyone is finding an avenue to commemorate Mr. Floyd."

48

Similarly, Associate Professor of African and American History at Albright College, Dr. Kami Fletcher, remarked on Floyd's gold casket on Twitter, "Y'all see the gold casket right? George Floyd is

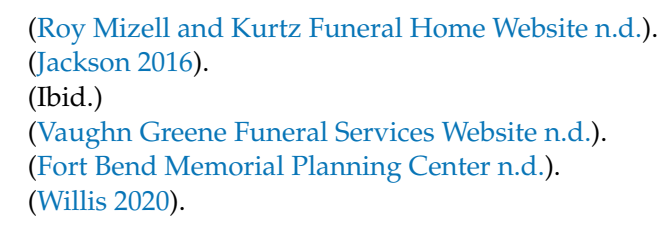


memorialized with the highest of honor and respect. African Americans have always used death material culture to resist, using last rites as a tool to subvert the racist, stereotypes caricature of thug and brute. ${ }^{\prime 49}$ The grandiosity of the funeral in Floyd's funeral is thus not only intentional but viewed as an act of resistance that demonstrates materially how much black lives do, in fact, matter. The open casket of Emmett Till, the closed caskets of the victims of the Birmingham bombing, and the gold casket of George Floyd all signal that black deaths matter, and will continue to matter until Black Lives Matter more. Just as Emmett Till's body was the burden of proof to convict Jim Crow, the bodies of Trayvon Martin, Tamir Rice, George Floyd, and others unjustly slain prove that Jim Crow's decedents-more covert forms of racism that plague our justice system are alive and well in the twenty-first century. The African American Funeral home continues to play an important role in American culture, and though its very existence, argues against racist policies and practices evident in the high mortality rates of blacks in the United States.

\section{Tokenism, Erasure, and White-Washing: The Whitening of Death Studies}

What does this mean for death studies and the field of thanatology? It is important to recover the diversity of American history and realize that much of the published work today on deathcare in the United States is one-sided and written primarily from a white and mostly protestant perspective. During the 1960s there were well over 4000 black funeral homes in the U.S., and today it is estimated that there are somewhere between 2800 and 3000, yet they have been written about in history as a token phenomenon and not a valuable and integral part of American Death Culture and History. Histories of death in the United States write about the white experience as the dominant cultural experience or tend to offer the African American experience of death as an interesting aside, as opposed to a core part of American death culture. ${ }^{50}$ The National Funeral Director's and Morticians Association (NFDMA) is generally mentioned as an aside rather than one of two major organizations representing the death industry, and yet the NFDMA has consistently published vibrant records of their organization and members that rarely get mentioned or examined. Important details of racism and death (combinations, segregated and unfair insurance policies, segregated cemeteries, etc.) have been forgotten or minimized while contributions by African Americans have been white-washed or forgotten. The hand-written records at Mother Bethel, for example, remain undigitized and unphotographed, with one librarian responsible for the management of their records. This is the oldest AME church in the United States, with one of the most important repositories on early American burial societies. Even today the African American funeral home continues to be a valuable yet ignored resource, while as Claudia Rankine notes, "the condition of black life is one of mourning."

So what can death scholars do to offer a corrective to the historical gaps in scholarship and the silences in thanatology? The entire story must be told. Thanatologists must not, though their own complicity, continue to forget and to be silent. The US Health and Human Services of Minority Health states that African Americans today have the highest mortality rate of any racial and ethnic group for all cancers combined, the death rates for all major causes of death are higher for blacks than for whites, and African American babies have an infant mortality rate twice that of non-Hispanic whites. Black Lives Matter, but Black Deaths are simply not mattering enough. As Eldridge Cleaver once said, "You don't have to teach people how to be human. You just have to teach them how to stop being inhuman." 52

49 (Fletcher 2020).

50 An example of this can be found in the way that the aids epidemic was written about in the 1980s or even the current work published on the opioid epidemic.

51 (Rankine 2015).

52 (Cleaver and Geismar 1968). 
Funding: This research was funded by The Louisville Institute Project Grant for Researchers, grant number \#2017040.

Conflicts of Interest: The author declares no conflict of interest.

\section{References}

Adkins, LaTrese Evette. 2003. And who has the body?: The Historical Significance of African American Funerary Display. Ph.D. dissertation, Michigan State University, East Lansing, MI, USA.

Armstead, Myra B. Young. 2005. Revisiting hotels and other lodgings: American tourist spaces through the lens of black pleasure-travelers, 1880-1950. The Journal of Decorative and Propaganda Arts 25: 136-59.

Arnold, Sandra A. 2016. Why Slaves' Graves Matter. New York Times. April 2. Available online: http://www. nytimes.com/2016/04/03/opinion/sunday/why-slaves-graves-matter.html?_r=0 (accessed on 10 April 2016).

Barrett, Ronald K. 1995. Contemporary African-American Funeral Rites and Traditions. In The Path Ahead: Readings in Death and Dying. Edited by Lynne Ann DeSpelder and Albert L. Strickland. Mountain View: Mayfield.

Blight, David W. 2002. Beyond the Battlefield: Race, Memory \& the American Civil War. Amherst: University of Massachusetts Press.

Butler, John Sibley. 2012. Entrepreneurship and Self-Help among Black Americans: A Reconsideration of Race and Economics. Albany: Suny Press.

Cann, Candi K. 2014. Virtual Afterlives: Grieving the Dead in the Twenty-First Century. Lexington: University Press of Kentucky.

Cann, Candi K. 2018. Mapping religious beliefs through consumer death goods1. In The Routledge Handbook of Death and the Afterlife. London: Routledge.

Cann, Candi K. 2020. African American Deathways. In Oxford Bibliographies in African American Studies. Edited by Gene Jarrett. New York: Oxford University Press.

Chapin, Christy Ford. 2012. "Going Behind with that Fifteen Cent Policy": Black-Owned Insurance Companies and the State. Journal of Policy History 24: 644-74. [CrossRef]

Chestnut Funeral Home Website. n.d. Available online: https://www.chestnutfh.com/ (accessed on 4 June 2019).

Cleaver, Eldridge, and Maxwell Geismar. 1968. Soul on Ice. New York: Dell.

DuBois, W. E. B. 1899. The Philadelphia Negro: A Social Study. New York: Schocken.

Fletcher, Kami. 2013. The City of the Dead for Colored People: Baltimore's Mount Auburn Cemetery, 1807-2012. Ph.D. dissertation, Morgan State University, Baltimore, MD, USA.

Fletcher, Kami. 2020. Tweet on June 4. Available online: https://twitter. com/kamifletcher36/status/1268580673515851776?s=12\&fbclid=IwAR39WW6NS7L_ sR5FPLLT1XYP75JJE1SU0FZsRR6ev3Ie70EfM840TCFPBrU (accessed on 5 June 2020).

Fort Bend Memorial Planning Center. n.d. Available online: https://www.fortbendmemorialpc.com/ (accessed on 4 June 2020).

Garza, Alicia. 2014. A Herstory of the \#BlackLivesMatter Movement. The Feminist Wire. October 7. Available online: https://thefeministwire.com/2014/10/blacklivesmatter-2/ (accessed on 1 June 2019).

Henderson, Angelo B. 1997. Death Watch? Black Funeral Homes Fear a Gloomy Future as Big Chains Move in. The Wall Street Journal. July 18. Available online: http://www.angelohenderson.com/articles/articlesby-angelo/55-death-watch-black-funeral-homes-fear-a-gloomy-future-as-big-chains-move-in (accessed on 25 November 2015).

Holland, Sharon Patricia. 2000. Raising the Dead: Readings of Death and (Black) Subjectivity. Durham: Duke University Press.

Homegoings. 2013. The African-American Funeral Director. January 24. Available online: http://www.pbs.org/ pov/homegoings/african-american-funeral-director/ (accessed on 10 April 2016).

J.F. Bell Funeral Home Website. n.d. Available online: https://jfbellfuneralservices.com/ (accessed on 4 June 2019). Jackson, Edwin. 2016. Black Funeral Directors and the Black Lives Matter Movement. Black Perspectives. January 24. Available online: https://www.aaihs.org/black-funeral-directors/\#fn-5512-4 (accessed on 21 May 2019).

Kaufman, Anna Belle. 1996. Art in boxes: An exploration of meanings. The Arts in Psychotherapy 23: $237-47$. [CrossRef]

Laderman, Gary. 2005. Rest in Peace: A Cultural History of Death and the Funeral Home in Twentieth-Century America. New York: Oxford University Press. 
Long, Jacob. 2014. Death \& Burials: The Final Frontier for Segregation. First Coast News. April 30. Available online: http://www.firstcoastnews.com/story/news/local/2014/04/30/segregation-jacksonvillecemetery-death-burials/8510995/ (accessed on 22 November 2015).

Massey, Douglas S., and Nancy A. Denton. 1993. American Apartheid: Segregation and the Making of the Underclass. Cambridge: Harvard University Press.

Measuring Worth Website. n.d. Available online: www.measuringworth.com (accessed on 25 March 2019).

National Funeral Directors \& Morticians Association, Inc. Website. n.d. Available online: http://www.nfdma.com/ contact.html (accessed on 22 November 2018).

Olwell, Robert. 1998. Masters, Slaves, E Subjects: The Culture of Power in the South Carolina Low Country, 1740-1790. Ithaca: Cornell University Press.

Poole Funeral Chapels Website. n.d. Available online: https://www.poolefuneralchapel.com/ (accessed on 4 June 2019).

Rankine, Claudia. 2015. The Condition of Black Life Is One of Mourning. Available online: https://www.nytimes. com/2015/06/22/magazine/the-condition-of-black-life-is-one-of-mourning.html (accessed on 1 June 2019).

Rayman, Graham. 2009. How Century-Old Burial Soceities Were Taken Over by Black Market Speculators. Village Voice. April 25. Available online: http://www.villagevoice.com/news/how-century-old-burialsocieties-were-taken-over-by-black-market-speculators-6389914 (accessed on 25 November 2016).

Renata, Cherlise. n.d. Black Archives. Available online: http://www.blvckvrchives.com/homegoing/ (accessed on 31 July 2018).

Roy Mizell and Kurtz Funeral Home Website. n.d. Available online: https://www.mizellandkurtzfuneralhome.com/ (accessed on 21 May 2019).

Semenya, David K. 2013. Burial Society versus the Church in the Black Society of South Africa: A Pastoral Response. Academic Journal of the Centre for Ministerial Development. April 17. Available online: http: //www.ve.org.za/index.php/VE/article/view/698/1219 (accessed on 25 November 2015).

Stanley, Tiffany. 2016. The Disappearance of a Distinctively Black Way to Mourn. The Atlantic. January 26. Available online: https:/www.theatlantic.com/business/archive/2016/01/black-funeral-homes-mourning/ 426807/ (accessed on 25 August 2018).

Valentine, Arzella J. n.d. The History of African-American Funeral Service. Woods Valentine Mortuary. Available online: http://www.woodsvalentinemortuary.com/The_History_of_African-American_Funeral_Service_ 320351.html (accessed on 25 November 2015).

Vaughn Greene Funeral Services Website. n.d. Available online: https://vaughncgreene.com/ (accessed on 21 May 2019).

Washington, Booker T. 1995. Up from Slavery. New York: Oxford University Press.

Willis, Kelcie. 2020. George Floyd: Memorial Service, Funeral Details Emerge. The Atlanta-Journal Constitution. June 2. Available online: https://www.ajc.com/news/national/george-floyd-memorial-service-funeral-detailsemerge/WhZiAZYbR1hlzmJ7iJrkKP/ (accessed on 4 June 2020).

(C) 2020 by the author. Licensee MDPI, Basel, Switzerland. This article is an open access article distributed under the terms and conditions of the Creative Commons Attribution (CC BY) license (http://creativecommons.org/licenses/by/4.0/). 